\title{
CERVICAL SPONDYLOSIS
}

\author{
PROGNOSTIC VALUE OF PREOPERATIVE SIGNS AND SYMPTOMS
}

\author{
REynaldo A. BRANDT * \\ ChaRLES A. FAGER **
}

Although the clinical picture in cervical radiculopathy and myelopathy due to spondylosis is well known nowadays $12,13,16,18,22$, its treatment is still a matter of discussion. Conflicting opinions exist regarding its pathogenesis and consequently different forms of treatment have been proposed. Bony spurs ${ }^{1}, 3,31$, compression of the anterior spinal artery ${ }^{15}$, vascular compression in the foramina ${ }^{2,29}$, atheromasia ${ }^{10}$, hypertrophic ligamenta flava ${ }^{3,}{ }^{15}$, cord deformity over a spondylotic ridge with flexion of the spine ${ }^{4}$ and its up-and-down movements ${ }^{24}$, have all been pointed as important factor is. pathogenesis, although some of them have been denied as such ${ }^{21,30}$.

Lees ${ }^{14}$ suggested that surgery does not benefit the patients more than conservative treatment and that "a very conservative approach should be the rule in patients with spondylotic myelopathy". Nurick ${ }^{20}$ found that results were similar in patients with surgical and conservative treatments. Keegan ${ }^{12}$ stated that "operation for relief of neurological symptoms caused by cervical spondylosis should be undertaken early before permanent nerve or cord damage have developed". Some authors 5, 17, 25 presented their results and preference for the anterior approach, while others prefer laminectomy $7,8,9,11$, $26,27,28$, with or without excision of bone spurs and with or without section of the dentate ligaments. Stoops and King ${ }^{27,}{ }^{28}$ did not find prognostic value in the age, sex, duration of symptoms per se, spinal fluid protein level, history of trauma, congenital abnormalities, number of transverse bars re quiring decompression and myelographic findings; profound quadripareses and severe atrophy in the upper limbs showed poor prognosis after surgery. Peserico et al. ${ }^{23}$ found that the duration of symptoms prior to surgery was of importance, with their degree. Combalbert and Pellet ${ }^{6}$ described better results in the younger patients. It is possible that different results are seen with the several forms of treatment; however, it is also probable that preoperative factors are important in the outcome of these patients. Thus, we decided to study our patients with cervical spondylosis, looking for a possible prognostic value in preoperative signs and symptoms. One hundred and forty-one patients with cervical spondylosis, surgically treated at the Lahey Clinic in Boston from 1967 to 1972 were studied.

Department of Neurosurgery, Lahey Clinic Foundation, Boston. Massachusetts, U.S.A.: *Fellow; ** Chairman. 


\section{RESULTS}

Radiculopathy - Pure radicular signs and symptoms were present in 99 patients; in other 23 these were associated to cervical myelopathy. C6 nerve root signs were found in $54.5 \%$ and $\mathrm{C7}$ nerve root in $51.4 \%$. Unilateral signs were present in $77.4 \%$ and bilateral in $22.6 \%$. The following surgical technique were used in those with pure radiculopathy: $a$ ) hemilaminectomy, foramenotomy and excision of bone spur, frequentily with excision of disc fragments (82 patientts); $b$ ) same, bilaterally (11 patients); c) anterior fusion in one level (4 patients); $d$ ) anterior fusion in two levels ( 2 patients).

Patients with myeloradiculopathy were treated by laminectomy and foramenotomy. The best surgical results could be seen after the first month, mainly between one and three months after surgery. $22.8 \%$ of those treated by hemilaminectomy had complete recovery and $59.6 \%$ marked improvement $(82.5 \%$ of excellent and good results); $12.3 \%$ had mild improvement. Two of those treated by anterior fusion in one level had marked improvement, one recovered completely and one had his symptoms arrested. One of those treated by anterior fusion in two levels had complete recovery in the first month after surgery and the other had his symptoms arrested in the first three months of follow-up.

Postoperative results compared to duration of the clinical picture (Table 1) $9.7 \%$ of the patients with radiculopathy came in the first month of symptoms; $55 \%$ came between the first and $12^{\text {th }}$ months after the onset and the remainding came between one and five years. Surgical results did not differ significantly in patients with clinical picture lasting from one month to five years untill treatment was established.

Postoperative results compared to the degree of the clinical picture (Table 2) Complete recovery was $2.5 \mathrm{X}$ more frequent in the patients with mild pareses of the upper limb compared to those with severe pareses; excellent and good results were seen in $82.6 \%$ of the former and in $75 \%$ of the latter. Complete recovery

\begin{tabular}{lcc}
\hline Duration of cl. picture & $\begin{array}{c}\text { Marked } \\
\text { improvement }\end{array}$ & Complete recovery \\
\hline
\end{tabular}

\section{Radiculopathy}

$\begin{array}{cccc} & \% & \% & \% \\ \text { One week or less } & 40.0 & 20.0 & 60.0 \\ 1 \text { w. }-1 \mathrm{~m} . & 25.0 & 58.3 & 83.3 \\ 1 \mathrm{~m} .-2 \mathrm{~m} . & 50.0 & 37.5 & 87.5 \\ 2 \mathrm{~m} .-6 \mathrm{~m} . & 45.5 & 42.4 & 87.9 \\ 6 \mathrm{~m} .-1 \mathrm{y} . & 66.7 & 37.0 & 81.4 \\ 1 \text { y. }-2 \text { y. } & 47.4 & 16.7 & 83.4 \\ 2 \text { y. }-5 \text { y. } & 66.7 & 0.0 & 73.7 \\ 5 \text { y. or more } & & 66.7\end{array}$

\section{Myelopathy}

$\begin{array}{lrrr}1 \mathrm{w} .-1 \mathrm{~m} . & 0.0 & 100.0 & 100.0 \\ 2 \mathrm{~m} .-6 \mathrm{~m} . & 42.9 & 28.6 & 71.5 \\ 6 \mathrm{~m} .-1 \mathrm{y} . & 60.0 & 10.0 & 70.0 \\ 1 \mathrm{y} .-2 \mathrm{y} . & 42.9 & 28.6 & 71.5 \\ 2 \mathrm{y} . & 60.0 & 0.0 & 60.0\end{array}$

Table 1 - Proportion of patients with marked improvement and complete recovery compared to duration of the clinical picture untill treatment: $w$. = week; m. = month; $y=$ year. 
was $4.5 \mathrm{X}$ more frequent in the patients without muscle atrophy in the upper limb compared to those with atrophy; excellent and good resuits were seen in $84.9 \%$ of the former and in $62.2 \%$ of the latter $(p<c .05)$. Complete recovery was less frequent in patients with hypoactive or absent reflexes in the upper limb. Patients with no sensory loss had complete recovery $4.5 \mathrm{X}$ more frequently than those with hypoesthesia. Complete recovery was $4 \mathrm{X}$ more frequent in patients with myelographic deffects in one or two disc levels, compared to those with more levels involved. Surgical results did not differ in patients with normal CSF protein level compared to those with abnormal levels.

\begin{tabular}{lrcc}
\hline & $\begin{array}{c}\text { Complete } \\
\text { recovery }\end{array}$ & $\begin{array}{c}\text { Marked } \\
\text { improvement }\end{array}$ & Total \\
\hline & & $\%$ & $\%$ \\
Severe pareses of the upper limb & 12.5 & 62.5 & $\mathbf{7 5 . 0}$ \\
Mild pareses of the upper limb & 31.6 & 51.2 & 82.6 \\
With atrophy in the upper limb & 8.7 & 56.5 & 65.2 \\
Without atrophy in the upper limb & 38.9 & 46.0 & 84.9 \\
Arreflexia in the upper limb & 33.3 & 53.3 & 86.6 \\
Hyporreflexia in the upper limb & 27.7 & 55.4 & 83.1 \\
Normorreflexia in the upper limb & 41.2 & 40.2 & 81.4 \\
With hypoesthesia in the upper limb & 8.3 & 66.7 & $\mathbf{7 5 . 0}$ \\
No hypoesthesia in the upper limb & 37.1 & 46.8 & $\mathbf{8 7 . 0}$ \\
One level involved & 38.8 & 48.2 & $\mathbf{8 5 . 3}$ \\
Two levels involved & 32.4 & 52.9 & $\mathbf{5 3 . 9}$ \\
Three levels involved & 7.7 & 46.2 & 66.7 \\
Four levels involved & 0.0 & 66.7 & \\
\hline
\end{tabular}

Table 2 - Proportion of patients with complete recovery and marked improvement compared to neurological signs and myelographic deffects in 122 patients with radiculopathy due to cervical spondylosis.

Postoperative results compared to age (Table 3 ) - $97.1 \%$ of the patients older than 60 years had mild or severe pareses of the upper limb, compared to $73.3 \%$ of the patients under 60 years with the same defficit. In the latter, excellent and good results were $2 \mathrm{X}$ more frequent than in the older patients.

Myelopathy - Spinal cord signs were present in 42 patients; 24 were treated by cervical laminecotomy and section of the dentate ligaments. Complete recovery was seen in $30.8 \%$ and marked improvement in $53.3 \%(84.1 \%$ of excellent and good results). Fourteen patients were treated by extensive cervical laminectomy without opening of the dura; $9.1 \%$ had complete recovery and $63.6 \%$ marked improvement $(72.7 \%$ of excellent and good results). These data cannot be compared because there were $20.8 \%$ of patients with severe pareses of the lower limbs in the first group and $46.7 \%$ of these in the second group. Three patients were treated by anterior fusion and laminectomy; after three months, only one had mild improvement of his symptoms.

Postoperative results compared to duration of the clinical picture (Table 1) $73.9 \%$ of the patients with myelopathy came in the first year of symptoms. Surgical results did not differ statistically in those with clinical picture lasting from two months to five years untill treatment was established. 
Postoperative results compared to the degree of the clinical picture (Table 4) No patient with severe pareses of the lower limbs had complete recovery in the first year after surgery; $29.4 \%$ of those with mild pareses had complete recovery in the same period of time. Marked improvement was seen in $66.7 \%$ of those with mild pareses and in $47.1 \%$ of those with severe pareses of the lower limbs $(p<0.1)$. No patient with severe spasticity of the lower limbs had complett recovery in the first postoperative year; excellent and good results were seen in higher proportion of patients with mild compared to those with severe spasticity. Five per cent of the patients with hypoesthesia of the lower limbs had complete recovery and $70 \%$ had marked improvement in the first three months after surgery; in the next period of time, untill 12 months after surgery, $16.7 \%$ had complete

\begin{tabular}{lcc}
\hline & $\begin{array}{c}\text { Younger than } \\
60 \text { years }\end{array}$ & $\begin{array}{c}\text { Older than } \\
60 \text { years }\end{array}$ \\
\hline \hline & $\%$ & $\%$ \\
Slight pareses of the upper limb & 26.7 & 2.9 \\
Mild pareses of the upper limb & 64.7 & 86.1 \\
Severe pareses of the upper limb & 8.6 & 11.0 \\
Excellent and good results & 64.6 & 32.3 \\
\hline
\end{tabular}

Table 3 - Proportion of patients with slight, mild and severe pareses of the upper limb and results after surgery compared to age in 122 patients with radiculopathy due to cervical spondylosis.

\begin{tabular}{|c|c|c|c|}
\hline & $\begin{array}{l}\text { Complete } \\
\text { recovery }\end{array}$ & $\begin{array}{c}\text { Marked } \\
\text { improvement }\end{array}$ & Total \\
\hline & $\%$ & $\%$ & $\%$ \\
\hline Mild pareses of the lower limbs & 29.4 & 47.1 & 76.5 \\
\hline Severe pareses of the lower limbs & 0.0 & 66.7 & 66.7 \\
\hline Mild spasticity of the lower limbs & 16.7 & 61.1 & 77.8 \\
\hline Severe spasticity of the lower limbs & 0.0 & 50.0 & 50.0 \\
\hline Hypoesthesia of the lower limbs & 16.7 & 66.7 & 83.4 \\
\hline Paresthesia only & 25.0 & 50.0 & 75.0 \\
\hline Hipoesthesia and paresthesia & 5.0 & 70.0 & 75.0 \\
\hline One disc level involved & 16.7 & 33.3 & 50.0 \\
\hline Two discs levels involved & 30.0 & 40.0 & 70.0 \\
\hline Three discs levels involved & 12.5 & 75.0 & 87.5 \\
\hline Four dises levels involved & 25.0 & 50.0 & 75.0 \\
\hline
\end{tabular}

Table 4 - Proportion of patients with complete recovery and marked improvement compared to neurological signs and myelographic deffects in 4.2 patients with myelopathy due to cervical spondylosis. 


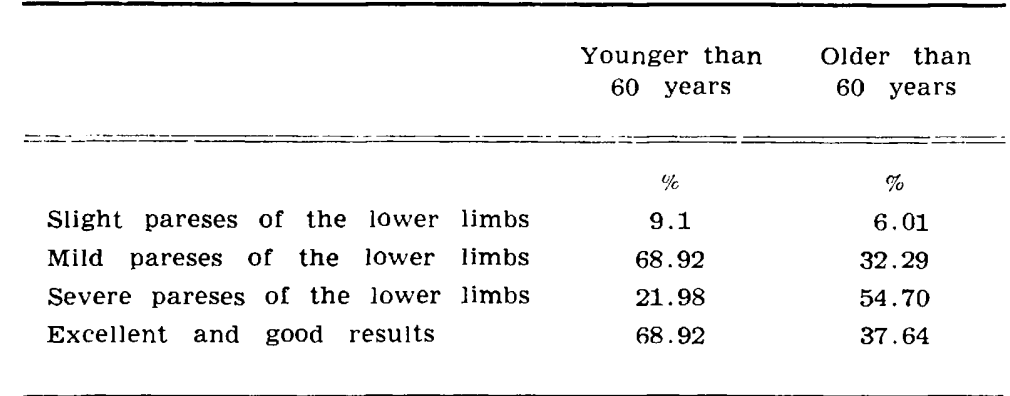

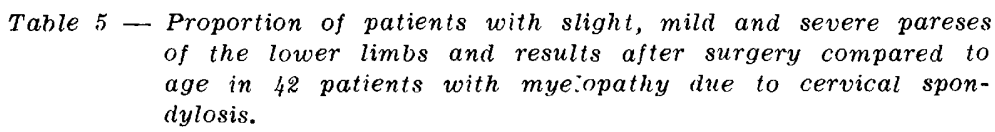

recovery and $66.7 \%$ marked improvement; $25 \%$ of the patients with paresthesia only but no objective sensory loss had complete recovery and 50\% marked improvement in the first three months; these results did not change untill 12 months after surgery. Patients with myelographic deffects in three levels had excellent and good results in higher proportion than those with two levels involved and these had better results than those with only one level deffect. There was no difference in the surgical results of patients with normal and abnormal CSF protein level.

Postoperative results compared to age (Table 5) - $16.6 \%$ of the patients with myelopathy were under 49 years; $66.6 \%$ were between 50 and 69 years old. Severe pareses was $2.5 \mathrm{X}$ more frequent in the older than 60 years and complete recovery was $2 \times$ less frequent in this age group $(p<0.05)$.

\section{DISCUSSION}

It is our impression that surgery has a definite place in the treatment of radiculopathy and myelopathy due to cervical spondylosis. It is particularly indicated in patients with progressive signs and symptoms. The surgical results can be predicted from the preoperative clinical picture. In our patients with radiculopathy, the degree of motor involvement of the upper limb, muscle atrophy, sensory involvement, number of myelographic deffects and age had prognostic value. In those with myelopathy, the degree of lower limbs pareses and spasticity, number of myelographic deffects and age had prognostic value. We found no such value in the time of duration of the clinical picture lasting from two months to five years and in abnormal CSF protein level. We think that, at least in part, conflicting results found in the literature are due to the difference in the degree of neurological damage of the patients considered by each author. Definite conclusions regarding the best method of treatment can only be drawn from similar groups of patients. However, it seems very obvious that surgery is a landmark in the recovery of patients with progressive signs and symptoms; the degree of some of these has a prognostic value and its standardization may lead to a better avaliation of the several surgical techniques. 
One hundred and forty-one patients with cervical spondylosis were studied, looking for a possible prognostic value in preoperative signs and symptoms. Duration of symptoms lasting from one month to five years untill surgical treatment and spinal fluid protein level had no prognostic value in these patients. In those with radiculopathy, the degree of upper limb pareses, muscle atrophy, absent or diminished reflexes, sensory involvement, number of myelographic deffects and age had prognostic value. In those with myelopathy, the degree of lower limbs pareses and spasticity, sensory involvement, number of myelographic deffects and age had prognostic value. Surgery is a definite method of treatment for patients with progressive signs and symptoms due to cervical spondylosis; some of the preoperative signs and symptoms are valuable in establishing their prognosis.

\section{RESUMO}

Espondilose cervicul: valor prognóstico dos sinais e sintomas pré-operatórios

Cento e quarenta e um pacientes com espondilose cervical foram estudados com o objetivo de se determinar um possível valor prognóstico nos sinais e sintomas pré-oreratórios; 99 apresentaram radiculopatia, 19 mielopatia e 23 mielorradiculopatia. Nos pacientes com radiculopatia, recuperação completa foi 2,5 vezes mais frequente nos com paresia moderada dos membros suceriores em relação aos com paresia intensa, 4,5 vezes mais frequente nos que não apresentaram atrofia muscular, 4,5 vezes mais frequente nos que não apresentaram distúrbios objetivos da sensibilidade, 4 vezes mais frequente nos que apresentaram defeitos mielográficos em menos do que dois niveis discais; pacientes com mais de 60 anos apresentaram maior proporção de comprometimento motor grave e também tiveram piores resultados com a cirurgia. Nos pacientes com mielopatia, nenhum com paresia intensa e nenhum com espasticidade intensa dos membros inferiores teve recuperação completa no primeiro ano após a cirurgia; resultados melhores foram observados nos que apresentaram paresia moderada nos membros inferiores. Melhores resultados foram vistos em pacientes com número maior de defeitos mielográficos. Comprometimento motor grave dos membros inferiores foi mais frequente nos pacientes com mais de 60 anos e estes apresentaram também piores resultados arós a cirurgia em relação aos com menos de 60 anos. A cirurgia foi um marco na recuperação destes pacientes. Conclui-se que a padronização da avaliação destes sinais e sintomas pré-operatórios permite um prognóstico em relação à radiculopatia e à mielopatia consequentes à espondilose cervical.

\section{REFERENCES}

1. ALLEN, K. L. - Neuropathies caused by bony spurs in the cervical spine with special reference to surgical treatment. J. Neurosurg. Psychiat. 15:20, 
1952 .

2. BRAIN, R. - Spondylosis; the known and the unknown. Lancet 1:687, 1954.

3. BRANDT, R. A. \& CARVALHO, R. R. D. - Espondilose cervical: estudo necroscópico de 50 colunas vertebrais. Neurobiol. (Recife) 36:9, 1973.

4. BREIG, A.; TURNBULL, I. \& HASSLER, O. - Effects of mechanical stress on the spinal cord in cervical spondylosis. A study on fresh cadaver material. J. Neurosurg. 25:45, 1966 .

5. CLOWARD, R. B. - The anterior approach for removal of ruptured corvical dises. J. Neurosurg. 15:602, 1958.

6. COMBALBERT, A. \& PELLET, W. - Indications thérapeutiques et résultats opératoires obtenus dans une série de 80 myélopathies par cervicalthrose. Thérapeutique (Fre) 48:498, 1972.

74 EPSTEIN, J. A.; CARRAS, R.; LAVINE, L. S. \& EPSTEIN, B. S. - The importance of removing osteophytes as part of the surgical treatment of myeloradiculopathy in cervical spondylosis. J. Neurosurg. 30:219, 1969.

8. FAGER, C. A. - Results of adequate decompression in the relief of spondylotic cervical myelopathy. J. Neurosurg. 38:684, 1973.

9. HAFT, H. \& SHENKIN, H. A. - Surgical end results of cervical ridge and disc problems. J. Amer. Med. Ass. 186.312, 1963.

10. HUTCHINSON, E. C. \& YATES, P. O. - The cervical portion of the vertebral artery. A clinico-pathological study. Brain 79:319, 1956.

11. KAHN, E. A. - The rôle of the dentate ligaments in spinal cord compression and the syndrome of lateral sclerosis. J. Neurosurg. 4:191, 1947 .

12. KEEGAN, J. J. - Dermatome hypalgesia with posterolateral herniation of lower cervical intervetebral disc. J. Neurosurg. 4:115, 1947.

13. KEEGAN, J. J. - The cause of dissociated motor loss in the upper extremity with cervical spondylosis. A case report. J. Neurosurg. 23:528, 1965.

14. LEES, F. \& TURNER, J. W. A. - Natural history and prognosis of cervical spondylosis. Brit. Med. J. 2:1607, 1963.

15. MAIR, W. G. P. \& DRUCKMAN, R. - The pathology of spinal cord lesions and their relation to the clinical features in protrusion of cervical intervertebral discs. Brain 76:70, 1953.

16. MAYFIELD, F. H. - Symposium on cervical trauma. Neurosurgical aspects. Clin. Neurosurg. 2:83, 1955.

17. MAYFIELD, F. H. - Cervical spondylosis: a comparison of the anterior and posterior approaches. Clin. Neurol. 13:181, 1965.

18. MURPHEY, F.; SIMMONS, J. C. H. \& BRUNSON, B. - Surgical treatment of laterally ruptured cervical discs. Review of 848 cases, 1939 to 1972 . J. Neurosurg. 38:679, 1973.

19. NUGENT, G. R. - Clinicopathologic correlations in cervical spondylosis. Neurology (Minneapolis) 9:273, 1959.

20. NURICK, S. - The pathogenesis of the spinal cord disorder associated with cervical spondylosis. Brain 95:87, 1972.

21. NURICK, S. - The natural history and the results of surgical treatment of the spinal cord disorder associated with cervical spondylosis. Brain 95:101, 1972 .

22. PALlis, C.; JONES, A. M. \& SPILLANE, J. D. - Cervical spondylosis. Incidence and implications. Brain $77: 274,1954$.

23. PESERICO, L.; UILHEIM, A. \& BAKER, G. S. - Surgical treatment of cervical myelopathy associated with cervical spondylosis. Acta Neurochir. 10: 365,1962 .

24. REID, J. D. - Effects of flexion-extension movements of the head and spine upon the spinal cord and nerve roots. J. Neurol. Neurosurg. Psychiat. 23:214, 1960.

25. ROBINSON, R. A.; WALKER, E.; FERLIC, D. C. \& WIECKING, D. K. The results of anterior interbody fusion of the cervical spine. $J$. Bone and Joint Surg. 44A:1569, 1962 .

26. SCOVILLE, W. B. - Cervical spondylosis treatment by lateral facetectomy and laminectomy. J. Neurosurg. 18:423. 1961. 
27. STOOPS, W. L. \& KING, R. B. - Neural complications of cervical spondylosis: their response to laminectomy and foramenotomy. J. Neurosurg. 19: $989,1962$.

28. STOOPS, W. L. \& KING, R. B. - Chronic myelopathy associated with cervical spondylosis. JAMA 192:281, 1965.

29. TAYLOR, A. R. \& ABERD, M. B. - Vascular factors in te myelopathy associated with cervical spondylosis. Neurology (Minneapolis) 14:62, 1964.

30. WILKINSON, M. - The morbid anatomy of cervical spondylosis and myelopathy. Brain 83:589, 1960.

31. WOLF, B. S.; KHILANI, M. \& MALIS, L. - The sagittal diameter of the bony cervical spinal canal and its significance in cervical spondylosis. $J$. Mount Sinai Hosp. 23:283, 1956.

Reynaldo A. Brandt - Address: Praca Osvaldo Cruz 138, cj. 73 - 04747 \$ão Paulo. SP - Brasil. 